\title{
Perbedaan Persepsi Mahasiswa Terhadap Kompetensi Preceptor Klinik Dan Preceptor Akademik pada Stase Keperawatan Dasar Profesi (KDP) Program Studi Ners Stikes Guna Bangsa Yogyakarta
}

\author{
Widuri Widuri
}

\section{Abstract}

Background: Clinical practice in nursing is an opportunity for all students to translate theoretical knowledge into actual action. In the clinic environment, students jwill be motivated by the suitability of competencies carried out through active participation in clinical learning, while thinking, action, and professional attitudes are played by clinical counselors (preceptors).

Objective: To know the difference between student perceptions of clinical preceptor competency and academic preceptor on Basic Nursing Professional Stase.

Research Method: This type of research uses descriptive comparative with cross sectional method. The population of this study was all Ners profession students. The research sample amounted to 48 respondents taken using the total sampling technique. Data collection uses questionnaires and the results of statistical tests used are T-test analysis.

Results: Based on the research, students 'perceptions of clinical preceptor competency in the medium category were $32(66.7 \%)$ and the students' perceptions of academic preceptor competencies in the high category were 26 (54.2\%). The results of the analysis of the T test ( $t$-test), obtained the value of tcount $=0.006$. Thus the value of tcount $<0.05$, it is stated that the hypothesis $\mathrm{Ha}$ is accepted.

Conclusion: There is a difference between student perceptions of clinical preceptor competency and academic preceptor on Basic Nursing Professional Stase (KDP).

Keywords: Student Perception, Clinical Preceptor, Academic Preceptor

\section{Pendahuluan}

Pendidikan Ners merupakan pendidikan akademik-profesional dengan proses pembelajaran yang menekankan pada tumbuh kembang kemampuan mahasiswa untuk menjadi seorang

Afiliasi Penulis

Prodi Ilmu Keperawatan Stikes Guna Bangsa Yogyakarta

Korespondensi kepada

Widuri

widuri_mahfud@yahoo.com akademisi dan profesional di bidang keperawatan (AIPNI, 2015). Untuk menghasilkan seorang perawat profesional, harus melewati dua tahap pendidikan yaitu tahap pendidikan akademik yang lulusannya mendapat gelar S.Kep. dan tahap pendidikan profesi yang lulusannya mendapat gelar Ners (Ns). Pada tahap akademik mahasiswa mendapatkan teori-teori dan konsep-konsep. Mata kuliah pada tahap ini terbagi menjadi kelompok mata kuliah yang sifatnya umum, mata kuliah penunjang seperti mata kuliah medis yang secara tidak langsung menunjang mata kuliah 
keperawatan dan mata kuliah keahlian berupa mata kuliah keperawatan. Sedangkan pada tahap pendidikan profesi mahasiswa mengaplikasikan teori-teori dan konsep-konsep yang telah didapat selama tahap akademik dalam praktik klinik.

Pembelajaran klinik merupakan fokus pembelajaran dan pengajaran yang melibatkan klien secara langsung dan menjadi "jantung" dari pendidikan keperawatan. Pada program profesi Ners, mahasiswa dimungkinkan untuk memperoleh kesempatan praktik sebanyak mungkin dan mengenal area klinik di awal pembelajaran (Nursalam \& Efendi, 2008). Lingkungan belajar klinik yang kondusif merupakan wadah atau tempat yang dinamis yaitu tempat dengan sumberdaya yang dinamis bagi para mahasiswa. Lingkungan klinik yang dipilih penting untuk mencapai objektif dan tujuan praktik klinik dalam sebuah program pendidikan keperawatan (Emilia, 2008).

Belajar di lingkungan klinik memiliki banyak keunggulan, salah satunya dapat berfokus pada masalah nyata dalam konteks praktik profesional. Mahasiswa termotivasi oleh adanya kesesuaian kompetensi yang dilakukan melalui partisipasi aktif pembelajaran klinik, sedangkan pemikiran, tindakan, dan sikap profesional diperankan oleh pembimbing klinik (preceptor). Menurut Mahen dan Clark (1996) dalam Nursalam \& Efendi (2008), preceptor adalah seorang perawat yang mengajar, memberikan bimbingan, dan dapat menginspirasi rekannya, menjadi tokoh panutan (role model), serta mendukung pertumbuhan dan perkembangan individu (trainee) untuk jangka waktu tertentu dengan tujuan mensosialisasikan trainee pada peran barunya.

Menurut (Dermawan, 2012) menyebutkan beberapa kriteria yang harus dimiliki oleh seorang preceptor. Adapun beberapa kriteria tersebut adalah sebagai berikut: berpengalaman dan ahli di lingkungan kerjanya, berjiwa kepemimpinan, mempunyai keterampilan komunikasi yang baik, mempunyai kemampuan membuat keputusan, mendukung perkembangan professional, mempunyai kemauan untuk mengajar dan mau mengambil peran dalam penerapan model preceptorship, tidak mempunyai sikap yang menilai terlalu awal pada rekan kerja, asertif, fleksibilitas untuk berubah, mampu beradaptasi dengan kebutuhan pembelajaran individu.

Adapun kompetensi preceptor terdiri dari lima kopetensi utama (Kantar, L.D, 2012) dan (Miller, J.A, 2013) adalah kolaborasi, karakter personal, fasilitas belajar, praktik profesional, dan pengetahuan tatanan klinik.

Berdasarkan hasil wawancara dengan koordinator profesi Ners STIKES Guna Bangsa Yogyakarta, menyatakan bahwa mahasiswa program profesi Ners akan mulai masuk stase pertama yaitu stase Keperawatan Dasar Profesi (KDP) pada bulan Oktober 2018 sehingga dibutuhkan banyak bimbingan dari preceptor klinik maupun preceptor akademik dalam melaksanakan peran barunya tersebut. Selain itu, preceptor yang digunakan belum semuanya mengikuti pelatihan preceptorship.

Dari beberapa hal yang diungkapkan pada latar belakang tersebut, maka perlu dilakukan studi untuk mengetahui perbedaan persepsi mahasiswa terhadap kompetensi preceptor klinik dan preceptor akademik pada stase Keperawatan Dasar Profesi (KDP) Program Studi Ners STIKES Guna Bangsa Yogyakarta.

\section{Metode}

Penelitian ini merupakan jenis penelitian noneksperimen dengan desain deskriptif komparatif dan metode kuantitatif, serta menggunakan pendekatan waktu cross sectional.

Penelitian telah dilakukan pada bulan Oktober 2018. Tempat penelitian ini dilakukan di Program Studi Ners STIKES Guna Bangsa Yogyakarta.

Populasi dalam penelitian ini adalah seluruh mahasiswa program profesi Ners STIKES Guna Bangsa Yogyakarta Tahun Akademik 2018-2019 yaitu sebanyak 51 orang. Teknik yang digunakan yaitu dengan cara sampling jenuh atau sensus/total sampling. Dengan demikian, maka peneliti mengambil sampel dari keseluruhan populasi mahasiswa program profesi Ners STIKES Guna Bangsa Yogyakarta sebanyak 51 orang. Akan tetapi, dalam pelaksanaan penelitian ada 3 orang mahasiswa tidak bersedia menjadi responden, sehingga jumlah sampel sebanyak 48 orang.

Kuesioner persepsi mahasiswa terhadap kompetensi Preceptor Klinik dan Preceptor 
Akademik, masing-masing terdiri dari 19 butir pernyataan, meliputi 16 butir pernyataan favourable dan 3 butir pernyataan unfavourable. Kategori penilaian bergerak dari 4 sampai dengan 1 untuk pernyataan favourable dan bergerak dari angka 1 sampai dengan 4 untuk pernyataan unfavourable.

Setelah kuesioner tersebut diisi selanjutnya untuk penentuan akhir skor ditotal yang diperoleh melalui penjumlahan dari nilai jawaban pada seluruh pernyataan. Skor tertinggi adalah 76 dan skor terendah adalah 19.

Uji validitas dan reliabilitas dilakukan oleh peneliti di STIKES Guna Bangsa Yogyakarta terhadap 20 responden. Berdasarkan uji validitas dan reliabilitas yang telah dilakukan didapatkan 19 pernyataan valid dengan nilai $r=0,315-0,838(>0$, 30) dan kuesioner dinyatakan reliabel dengan nilai Cronbach's Alpha sebesar 0,801 $(>0,6)$.

\section{Hasil \& Pembahasan}

\section{Karakteristik Responden}

Berdasarkan hasil distribusi data tentang jenis kelamin responden pada tabel 1 , diketahui bahwa paling banyak adalah perempuan, yaitu sebanyak 31 orang $(64,6 \%)$, usia kisaran antara 21-25 tahun yaitu sebanyak 44 orang $(91,7 \%)$ dan mahasiswa paling banyak praktik di RSUD Salatiga yaitu sebanyak 16 orang (33,3\%).

\section{Persepsi Mahasiswa Terhadap Kompetensi}

\section{Preceptor Klinik}

Berdasarkan hasil distribusi data tentang persepsi mahasiswa terhadap kompetensi preceptor klinik pada tabel 2, diketahui bahwa paling banyak persepsi mahasiswa pada kategori sedang yaitu 32 responden $(66,7 \%)$.

Hasil ini sejalan dengan penelitian yang dilakukan oleh Shalahudin et.al (2018), yang berjudul Pengaruh Kompetensi dan Motivasi Pembimbing Klinik terhadap Kinerja dalam Membimbing Praktek Klinik di RSUD Dr.Slamet Garut pada Tahun 2015. Diperoleh hasil bahwa kompetensi pembimbing klinik pada kategori sedang, yaitu sebanyak 24 responden (48\%). Hal ini menunjukkan bahwa sebagian besar responden mempunyai persepsi bahwa kompetensi preceptor klinik cukup baik.
Tabel 1 | Distribusi Frekuensi Responden Berdasarkan Jenis Kelamin, Usia dan Tempat Praktik.

Karakteristik Responden Jumlah

(n) \%

Jenis Kelamin

\begin{tabular}{llll} 
& Laki-laki & 17 & 35,4 \\
\cline { 1 - 2 } & Perempuan & 31 & 64,6 \\
Usia & & &
\end{tabular}

\begin{tabular}{|ccc|}
\hline 21-25 tahun & 44 & 91,7 \\
\hline 26-30 tahun & 3 & 6,2 \\
\hline $31-35$ tahun & 1 & 2,1
\end{tabular}

\section{Tempat Praktik}

\begin{tabular}{lcc}
$\begin{array}{l}\text { RSUD } \\
\text { Sleman }\end{array}$ & 6 & 12,5 \\
$\begin{array}{l}\text { RS } \\
\text { Hardjolukito }\end{array}$ & 15 & 31,2 \\
$\begin{array}{l}\text { RSUD } \\
\text { Prambanan }\end{array}$ & 11 & 22,9 \\
$\begin{array}{l}\text { RSUD } \\
\text { Salatiga }\end{array}$ & 16 & 33,3 \\
\hline Total & 48 & 100 \\
\hline
\end{tabular}

Tabel 2 | Distribusi Frekuensi Responden Berdasarkan Persepsi Mahasiswa terhadap Kompetensi Preceptor Klinik No Persepsi Mahasiswa terhadap Kompetensi Preceptor Klinik

Frekuensi
$(n=48)$

\begin{tabular}{cccc}
\hline 1 & Tinggi & 16 & 33,3 \\
$\mathbf{2}$ & Sedang & 32 & 66,7 \\
$\mathbf{3}$ & Rendah & 0 & 0 \\
\hline & Total & 48 & 100
\end{tabular}

Hal ini disebabkan karena adanya kerjasama dan kepercayaan antara preceptor dan mahasiswa. Hal ini sesuai dengan pendapat Keen (2009), bahwa pendidikan klinik melibatkan kerjasama dan berbagi pengalaman antara preceptor dan mahasiswa praktik, dan saling memberikan dukungan dan kepecayaan dalam lingkungan pembelajaran. Pendidikan klinik tidak hanya memberikan ceramah, informasi dan demonstrasi keterampilan, tetapi melibatkan partisipasi aktif mahasiswa dalam pembelajaran.

\section{Persepsi Mahasiswa Terhadap Kompetensi Preceptor Akademik \\ Berdasarkan hasil distribusi data tentang persepsi mahasiswa terhadap kompetensi}


Tabel 3 | Distribusi Frekuensi Responden Berdasarkan Persepsi Mahasiswa terhadap Kompetensi Preceptor Akademik

\begin{tabular}{lccc} 
No & $\begin{array}{l}\text { Persepsi Mahasiswa } \\
\text { terhadap Kompetensi } \\
\text { Preceptor Akademik }\end{array}$ & $\begin{array}{c}\text { Frekuensi } \\
\text { (n=48) }\end{array}$ & \% \\
\hline $\mathbf{1}$ & Tinggi & 26 & 54,2 \\
\hline $\mathbf{2}$ & Sedang & 22 & 45,8 \\
$\mathbf{3}$ & Rendah & 0 & 0 \\
& Total & 50 & 100
\end{tabular}

preceptor akademik pada tabel 3, diketahui bahwa paling banyak persepsi mahasiswa pada kategori tinggi, yaitu 26 responden (54,2\%).

Hasil ini menunjukkan bahwa sebagian besar responden mempunyai persepsi bahwa kompetensi preceptor akademik baik. Hal ini disebabkan karena semua preceptor akademik telah mengikuti pelatihan preceptorship.

Preceptorship disebut juga pembelajaran klinik merupakan salah satu metode mendidik peserta didik di klinik yang memungkinkan pendidikan memilih dan menerapkan cara mendidik yang sesuai dengan objektif (tujuan), dan karakteristik individual peserta didik berdasarkan kerangka konsep pembelajaran (Nursalam, 2007). Pelaksanaan preceptorship yang terjadi selama pengalaman praktek mahasiswa di tempat pelayanan kesehatan, memberikan kesempatan bagi mahasiswa untuk mengaplikasikan teori yang telah dipelajari di akademik ke dalam praktek di tempat pelayanan kesehatan, sehingga pengalaman mahasiswa selama di klinik sangat bermanfaat dalam pembelajaran akademik.

\section{Perbedaan Antara Persepsi Mahasiswa}

Terhadap Kompetensi Preceptor Klinik dan

\section{Preceptor Akademik}

Data pada peneilitian ini diolah dengan menggunakan uji beda T-test untuk mengetahui perbedaan antara persepsi mahasiswa terhadap kompetensi preceptor klinik dan preceptor akademik.
Berdasarkan pada tabel 4, hasil uji perbedaan persepsi mahasiswa terhadap kompetensi preceptor klinik dan preceptor akademik menunjukkan nilai ${ }^{\mathrm{t}}$ statistik sebesar $-2,866$ dan probabilitas sebesar $0,006<0,05$. Dengan demikian, terdapat perbedaan yang signifikan antara persepsi mahasiswa terhadap kompetensi preceptor klinik dan preceptor akademik. Hasil rata - rata persepsi mahasiswa menunjukkan bahwa kompetensi preceptor akademik lebih tinggi dibandingkan dengan kompetensi preceptor klinik, yaitu ada selisih sebesar 0,2084 point.

Hal ini disebabkan karena sebagian preceptor klinik belum terpapar pelatihan preceptorship. Preceptorship merupakan suatu cara dalam bimbingan klinik yang memakai role model sebagai cara untuk mendukung pembelajaran dan perkembangan profesional keperawatan dan untuk mendukung kualitas lingkungan praktek. Pendekatan yang dilakukan dalam pembelajaran klinik ini adalah pendekatan hubungan satu-satu, belajar mandiri, memberikan lingkungan yang aman sebagai refleksi dan berfikir kritis, pemberian nasihat, konseling, bimbingan, memberikan kekuatan dan umpan balik yang konstruktif. Bagaimanapun juga pembelajaran klinik digunakan khusus dalam proses formal yaitu dalam membantu praktisi pemula untuk memperoleh kompetensi praktek awal melalui supervisi langsung melalui waktu yang pendek (CNA, 2004).

Pelaksanaan preceptorship yang terjadi selama pengalaman praktek mahasiswa di tempat pelayanan kesehatan, memberikan kesempatan bagi mahasiswa untuk mengaplikasikan teori yang telah dipelajari di akademik ke dalam praktek di tempat pelayanan kesehatan, sehingga pengalaman mahasiswa selama di klinik sangat bermanfaat dalam pembelajaran akademik. Dosen dan perawat merupakan sumber informasi untuk berbagi tujuan dalam membantu pembelajaran dan pencapaian pengetahuan baru. Pembelajaran klinik harus dilihat sebagai model tambahan, yang mengakui lulusan baru yang berkompeten dan

Tabel 4 | Hasil Uji Perbedaan Persepsi Mahasiswa terhadap Kompetensi Preceptor Klinik dan Preceptor Akademik.

\begin{tabular}{cccccc} 
Variabel & Kompetensi & Rata-rata & t hitung & Sig & Keterangan \\
\hline Persepsi & Preceptor Klinik & 2,3333 & $-2,866$ & 0.006 & Ada perbedaan \\
Mahasiswa & Preceptor Akademik & 2,5417 & & & \\
\hline
\end{tabular}


pemula praktisi yang akan terus mengembangkan kompetensi mereka sebagai bagian dari pengembangan karir mereka atau pengembangan profesional berkelanjutan, bukan sebagai individu yang perlu untuk mengatasi defisit dalam hal pendidikan dan pelatihan (Keen, 2009).

\section{Kesimpulan}

Studi ini menunjukkan persepsi mahasiswa terhadap kompetensi preceptor klinik pada stase Keperawatan Dasar Profesi pada kategori sedang $(66,7 \%)$. Sedangkan persepsi mahasiswa terhadap kompetensi preceptor akademik pada stase Keperawatan Dasar Profesi pada kategori tinggi (54,2\%).

Analisa lebih lanjut menunjukkan adanya perbedaan antara persepsi mahasiswa terhadap kompetensi preceptor klinik dan preceptor akademik pada stase Keperawatan Dasar Profesi (nilai $\mathrm{t}$ statistik sebesar $-2,866$ dan probabilitas sebesar $0,006<0,05)$..

\section{Bibliografi}

1. AIPNI. 2015. Kurikulum Inti Pendidikan Ners Indonesia 2015. Jakarta: AIPNI.

2. CNA. 2004. Achieving Excellence in Professional Practice. Ottawa.

3. Dermawan, D. 2012. Mentorship dan Preceptorship dalam Keperawatan. Jurnal Akper Poltekkes Bhakti Mulia Sukoharjo.

4. Emilia, O. 2008. Kompetensi dan lingkungan belajar klinik di rumah sakit. Yogyakarta: Gajah Mada University Press.

5. Kantar, L.D. 2012. Clinical Practice of New Nurse Graduates in Lebanon: Challenges and Perspectives Through the Eyes of Preceptors. J Contin Educ Nurs. 43(11):518-528.

6. Keen, A. 2009. Preceptorship Framework for Newly Registered Nurses, Midwives, and Allied Health Professionals. Dalam C.D. Deparment of Health. London: 17 Maret 2010.

7. Miller, J.A. 2013. The Lived Experiences Of Nurses Transitioning To A Preceptor Role. Department of Counseling, Adult and Higher Education. Northern Illinois University. Gene Roth and Larinda Dixon, CoDirectors.

8. Nursalam. 2007. Manajemen Keperawatan: Aplikasi dalam Praktik Keperawatan Profesional. Jakarta: Salemba Medika.
9. Nursalam \& Efendi, F. 2008. Pendidikan dalam Keperawatan. Jakarta: Salemba Medika.

10. Shalahudin, I et.al. 2018. Pengaruh Kompetensi dan Motivasi Pembimbing Klinik terhadap Kinerja dalam Membimbing Praktek Klinik di RSUD dr. Slamet Garut Tahun 2015. Jurnal Kesehatan Bakti Tunas Husada Volume 18 Nomor 1, Februari 2018. 